\title{
Morphological variation in the coral genus Platygyra: environmental influences and taxonomic implications
}

\author{
K. J. Miller \\ Marine Biology Department, James Cook University of North Queensland, Townsville, Qld. 4811, Australia
}

\begin{abstract}
Scleractinian corals are notoriously variable and the high degrees of morphological variation displayed by some species, particularly in response to environmental influences, confound our understanding of species boundaries. In order to fully understand the ranges of variation and the influence of habitat on colonies within the genus Platygyra, levels of intra- and interspecific morphological variation were quantified and colony morphology was examined relative to environmental gradients. Measurements of 9 skeletal characters of colonies of Platygyra were analysed by multivariate analysis of variance and canonical discriminant analysis to examine morphological species boundaries. While the taxonomic literature suggests the existence of 5 morphological species of Platygyra, results from this study suggest there may be 7 present on the Great Barrier Reef, Australia. A comparison of skeletal characters of 2 species, $P$. daedalea and $P$. pini, across 4 different habitats indicates that the environment does not influence skeletal characteristics in these species. Similarly, a detailed survey of distribution patterns of Platygyra spp. indicates that all species occur sympatrically across 6 reef habitats and that colony morphology does not change predictably along environmental gradients. The absence of any association between morphology and habitat in Platygyra suggests environment has little influence on morphology in these species. Numerical techniques are likely to be useful for defining species boundaries in highly variable groups of corals and similarly for understanding ranges of intraspecific morphological variation.
\end{abstract}

KEY WORDS: Coral · Morphological variation $\cdot$ Species boundaries

\section{INTRODUCTION}

Often many species display a wide range of morphologies in response to habitat differences. Such environmental influences on morphology have been documented in a variety of taxa, particularly those with a sessile mode of life such as plants and corals. The ability of an organism to change morphology according to habitat is important not only in taxonomy, but also ecologically and has resulted in the introduction of concepts such as clines (Huxley 1938), ecotypes (Turesson 1922) and ecomorphs (Veron \& Pichon 1976). Phenotypic responses to environmental influences are often high due to heterogeneity of environments and this is particularly relevant in coral reef systems. In order to understand the processes that determine observed patterns of morphological variation, it is nec- essary to understand the potential of a species to alter its morphology. Similarly, the potential of an organism to respond to environmental influences will be relevant when considering the range of variation that can be exhibited by a single species and ultimately when considering species boundaries.

Intraspecific morphological variation is high within the Scleractinia and hence its consequences for coral taxonomy are important. The majority of taxonomy in the Scleractinia has been based on morphology (e.g. Ellis \& Solander 1786, Vaughan \& Wells 1943, Chevalier 1975, Veron et al. 1977, although see Lang 1984). Not surprisingly, the existence of high degrees of morphological variation has confounded taxonomists, resulting in continual reclassification at the species level. Morphological features may differ from coral to coral within a species, even from polyp to polyp within 
a colony, and are likely to be highly inconsistent between species groups (e.g. Veron et al. 1977). Numerical taxonomic methods have been applied to some groups of corals with success (e.g. Powers \& Rohlf 1972, Wallace 1974, Brakel 1977) and may prove extremely useful not only in improving the consistency of assigning corals to species groups but also in understanding morphological variation within species (Foster 1980. Van Veghel \& Bak 1993)

Habitat influences may contribute to much of the morphological variation in corals and variation in skeletal characters has been reported to correspond with environmental parameters such as depth (Barnes 1973) and light attenuation (Jaubert 1977, Graus \& Macintyre 1982). Transplant experiments have demonstrated the effect of habitat on both colony shape (Dustan 1975, Oliver et al. 1983, Willis 1985) and calicular skeletal characters (Foster 1979). Conversely, morphological vanation in some species may be solely genetically controlled (e.g. Pavona cactus; Willis 1985 , Willis \& Ayre 1985). While it is now widely accepted that a single coral species may display a wide variety of morphotypes (e.g. Veron 1981), species boundaries in some groups remain unclear. Faviid corals in particular represent a highly variable taxonomic group in which morphological characters of different species intergrade (Wijsman-Best 1974, Veron et al. 1977).

The genus Platygyra occurs throughout the IndoPacific and displays much of the morphological variation associated with the Faviidae, of which it is a member. Colonies are generally massive with long, meandroid valleys, although some colonies may become plate-like. Valley lengths range from monocentric ( $P$. pini) to continuous $(P$. daedalea). There are 5 species of Platygyra currently recorded from the Great Barrier Reef, Australia - P. daedalea, P. sinensis, P. pini, P. lamellina and P. ryukyuensis (Veron 1993) - although species definitions are purely qualitative and encompass a broad range of variation. There is much apparent overlap in skeletal characteristics across species of Platygyra (see Stephenson \& Wells 1955) and while 'typical' specimens of a species group are easily assigned, it is not always possible to allocate any one skeleton to a particular species. Habitat may have an important influence on the morphology of Platygyra colonies. Veron et al. (1977, page 98) state in reference to Platygyra that 'specific differences may become obscure in large collections from a variety of biotopes, where the skeletal characters of one species overlap with those of another from a different biotope'. Similarly, Wijsman-Best (1974) suggested that variation in skeletal characters in $P$. daedalea may be related to depth.

In order to remove subjectivity in the determination of species in the Scleractinia, a more detailed approach to understanding both phenotypic and genotypic mor- phological variation is necessary. This paper aims to apply numerical taxonomic methods, in particular canonical variate analysis, to examine morphological variation both within and between species of Platygyra. In addition, spatial distribution patterns of morphological variants of Platygyra are documented and morphological differences are examined relative to environmental gradients. By combining such information, morphological species boundaries, the range of intraspecific morphological variation and the role of habitat on the morphology of Platygyra species can be more fully understood

\section{METHODS}

Interspecific variation. Sampling: Colonies of Platygyra daedalea, $P$. sinensis, $P$. pini and $P$. ryukyuensis (icieniified in the field according to Veron et al. 1977 , Veron 1986) were collected from Davies Reef, central Great Barrier Reef ( $18^{\circ} 51^{\prime}$ S, $\left.147^{\circ} 38^{\prime} \mathrm{E}\right)$. A fifth species, $P$. lamellina, was not found at Davies Reef, hence colonies werc collected from Orpheus Island $\left(18^{\circ} 35^{\prime} \mathrm{S}\right.$, $146^{\circ} 29^{\prime} \mathrm{E}$ ). Large portions (approximately $30 \times 30 \mathrm{~cm}$ ) were chiselled from colonies for morphometric analysis to examine skeletal differences between species groups. Colonies from a range of depths and habitats (see below) were used in order to encompass the complete range of intraspecific variation in defining species boundaries. There are no diagnostic skeletal characters which distinguish the 5 species of Platygyra, hence for the morphometric comparison of species groups, I used measurements of 9 common skeletal characters (Fig. 1). Skeletal characters were measured using a combination of computer image-analysis and hand measurements with callipers. An initial pilot study was carried out to determine within-and between-colony variability for each skeletal character using estimates of precision and variance components. This study indicated that high sample precision $(<0.2)$ would be obtained by measuring 10 replicates of each skeletal character on each of 6 replicate colonies of each species (Miller 1994). Hence characters were measured in 10 randomly chosen polyps or valleys from 6 replicate colonies of each of the 5 Platygyra species (except P. ryukyuensis where only 3 colonies were measured). Care was taken when measuring valleys to avoid the growing edges of the colonies as these often display atypical skeletal patterns (pers. obs.; see also Barnes 1973).

Analysis: Data were tested for normality and heteroscedasticity using SAS (proc GLM). The majority of characters were normally distributed, hence all analyses were done on raw data. Mean values of characters for each colony were used in analyses and species groups were compared using multivariate analysis of 
Fig. 1. Diagrammatic representation of skeletal measurements taken on colonies of Platygyra. VW: valley width measured from the middle of the theca on either side of the valley: CW: columella width measured parallel to valley width, from the edges of the columella; ST: septa thickness measured on primary septa, parallel with the theca edge; TT: theca thickness measured approximately halfway up its height; VD: valley depth measured vertically from the columella to the top of the septa; ES: exertness of septa above the theca. Other measurements taken but not illustrated were VL: valley length measured from the top centre of the theca at each end of the valley; SCM: total number of septa occurring along a theca length of $1 \mathrm{~cm}$; PA: the approximate area of an individual polyp calculated as the valley area divided by the total number of polyps in the valley

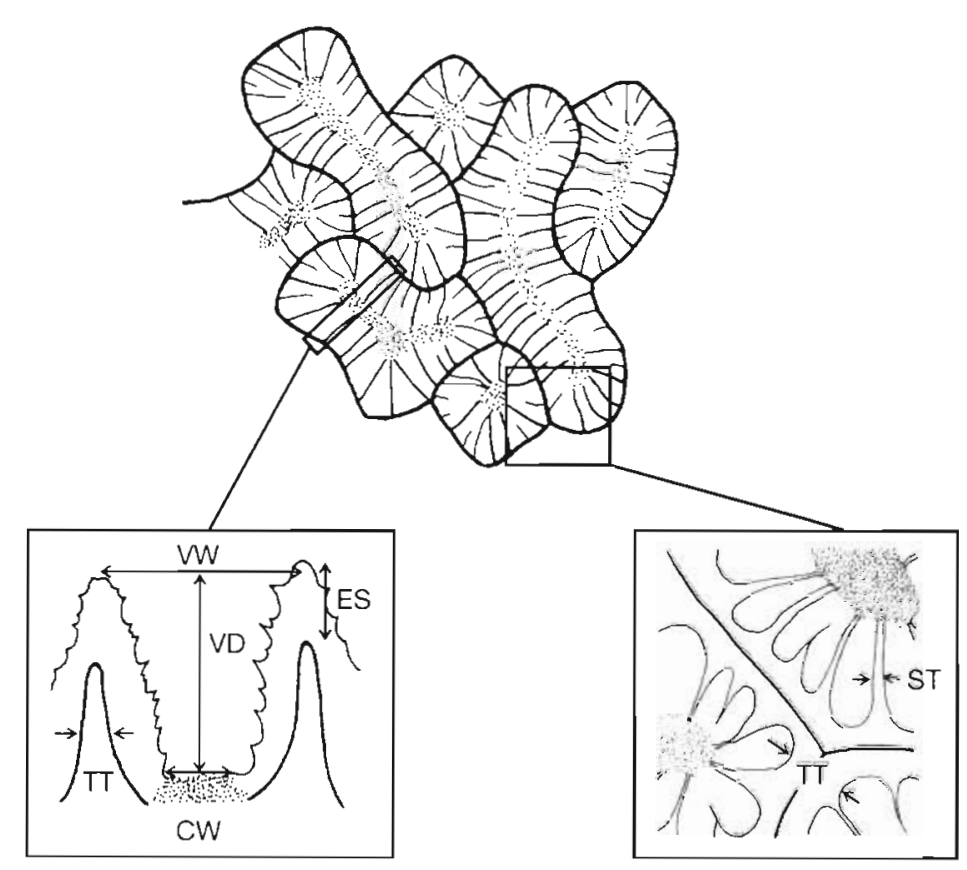

variance (SAS proc GLM) to determine if skeletal characters differed between species. Canonical discriminant analysis (SAS proc CANDISC) was used to visually examine the morphological differences between the species groups.

Intraspecific variation. One species, Platygyra daedalea, was chosen for extensive analysis of intraspecific variation. Seven different morphological variants within the species $P$. daedalea were identified $a$ priori, based on field appearances and gross colony form. These morphs were defined as follows (see also Miller in press): (1) Classic (PDC) - has a massive, hemispherical growth form and long, meandroid valleys. Theca width is constant within the colony, corallite walls are steep sided forming $U$-shaped valleys in cross section and septa are moderately exert. (2) Shortvalley (PDSV) - as for PDC, however valleys are short to monocentric. (3) Encrusting (PDSE) - colonies are flattened and encrusting, often plate-like. Valleys generally run parallel to each other and are perpendicular to the line of colony growth. Corallite walls are steep, the theca thin and septa are highly exert. (4) Hillocky ( $\mathrm{PH})$ - colonies have a massive, hillocky growth form, valleys are long and meandroid and are $\mathrm{V}$-shaped. Theca thickness is variable within a colony, ranging from wide with rounded septa on convex surfaces to thin with highly exert septa on concave surfaces. (5) Miniature (PB) - a massive colony often with a hillocky growth form and neat regular appearance, valleys are long and meandroid with relatively small polyps, septa are regularly spaced and meet above the theca forming a ridge. (6) Fat (PDF) - colonies are similar in appearance to the classic morph, however the theca is wider and septa more rounded (although not as much as P. lamellina). (7) Fat/intermediate (PDFI) - these colonies have thecae intermediate in width between the classic and fat morphs, have moderately exert septa and a massive growth form. Skeletal measurements (as described above) were taken on 6 colonies of each of the 7 morphs (except morph PB where only 5 colonies were measured) and analysed using canonical discriminant analysis, in order to examine the range and degree of variation within a single species.

Environmental variation. To determine if changes in morphology were apparent along environmental gradients, a detailed study of the distribution patterns of each of the species and morphs of Platygyra was carried out across the reef at Davies Reef. The abundance of different species and morphs of Platygyra was examined in 6 different environmental reef zones: (1) the front reef slope (forereef) at $10 \mathrm{~m}$ depth (F10); (2) the front reef slope (forereef) at $5 \mathrm{~m}$ depth (F5); (3) the front reef flat (a region approx, $20 \mathrm{~m}$ inwards from the reef crest) (FRF); (4) the lagoon (approx. $3 \mathrm{~m}$ deep) (LAG); (5) the back reef flat (BRF); and (6) the back reef slope at approximately $5 \mathrm{~m}$ depth (BACK). Within each zone 4 different sites were chosen (approximately equidistant along the reef length) and within each site eight $20 \times 1 \mathrm{~m}$ replicate belt transects were surveyed, recording the species (and morphological type for $P$. daedalea) of all Platygyra colonies. Rare morphs not found in the transects but which were seen adjacent to the transects were also noted. The abundance (i.e. the number of colonies per site) of each of the species and morphs in each zone was compared using analysis of variance (SAS proc GLM). 
In addition, to assess further the influence of environment on Platygyra morphology, skeletal characters were compared across 4 of the reef zones described above (F10, F5, LAG, BACK). Colonies of 2 species, $P$. daedalea and $P$. pini, were used for this comparison. Both species are common, widely distributed and represent either end of the morphological gradient within the genus. $P$. pini has relatively small, monocentric polyps and small colony size. In contrast $P$. daedalea has long, meandroid valleys, relatively large polyps and forms large colonies. Six colonies of $P$. daedalea (morph PDC) and 6 colonies of $P$. pini from each zone were measured (as described above). Skeletal characters of conspecific colonies from the 4 zones were compared using muitivariate analysis of variance to determine if measured skeletal characters varied significantly between different environmental regions.

\section{RESULTS}

\section{Interspecific variation}

The application of numerical taxonomic methods to the genus Platygyra suggested the existence of 7 , rather than 5, morphologically distinct species groups as have been described in the literature. There was no single diagnostic character suitable for isolating the 7 different species as the ranges of variation in all characters overlapped between groups (Table 1). However, MANOVA based on 9 skeletal characters of 98 colonies was significant (Pillai's Trace $=3.79, F=5.55, \mathrm{df}=100$, $p<0.001$ ) indicating that morphological differences do exist between the species groups when all characters are considered simultaneously. Canonical discriminant analysis (CDA) showed that $86 \%$ of the variation between groups was explained by the first 3 canonical variables and a plot of the first 2 canonical variables clearly identified differences between 4 of the species groups: $P$. lamellina, $P$. sinensis, $P$. daedalea and the group $\mathrm{PH}$ (initially considered here to be a morphological variant of $P$. daedalea) (Fig. 2). Plots of other canonical variates were also examined but revealed no further group-

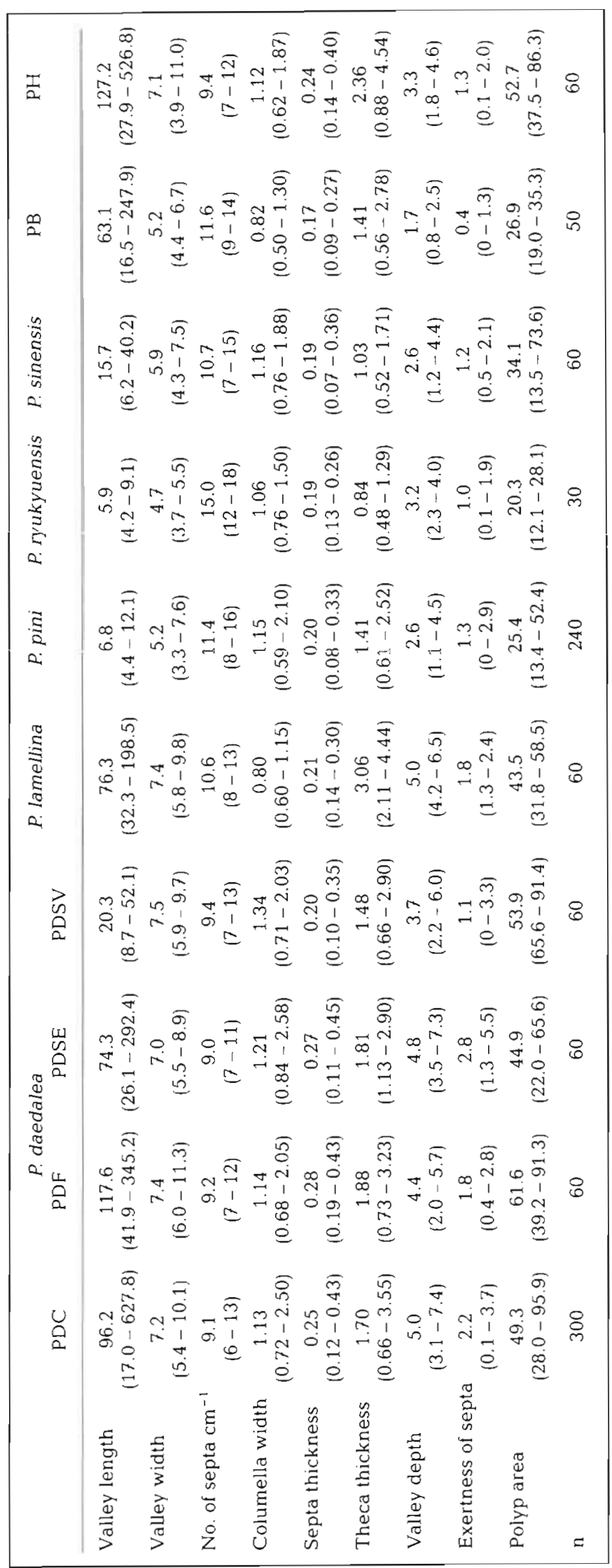


ings. Overall size was represented by the first canonical variable which was largely contributed to by all characters except columella width (Fig. 2). The character theca thickness was important in the separation of P. lamellina and the group PH (Fig, 2), P. lamellina had a mean theca thickness of $3.1 \mathrm{~mm}$, compared to $2.4 \mathrm{~mm}$ for PH and between 0.8 and $2 \mathrm{~mm}$ for the other groups (Table 1). Polyp size followed a distinct gradient along the $x$-axis from those with the smallest polyps ( $P$. pini, $P$. ryukyuensis, $P$. sinensis and $\mathrm{PB}$ ) through to those with larger polyps ( $P$. daedalea, $P$. lamellina and $\mathrm{PH}$ ) (Fig. 2). Separation of the small-polyped group of species was unclear based on this analysis, probably due to the influence of the large-polyped group of species (Fig. 2). A second CDA, performed on only the small-polyped groups, clearly defined differences between the species $P$, pini, $P$. ryukyuensis, $P$. sinensis and the group PB (initially considered a morph of $P$. daedalea) (Fig. 3). The group PB was separated largely on valley length, $P$. sinensis on polyp area and valley width and $P$. ryukyuensis on number of septa per $\mathrm{cm}$ (Fig. 3). There were no misclassifications of skeletons into a priori groups, hence the groups and the morphological differences between them are realistic.

\section{Intraspecific variation}

While Platygyra daedalea was initially divided into 7 different morphological variants based on field appearances (see 'Methods'), the analyses described

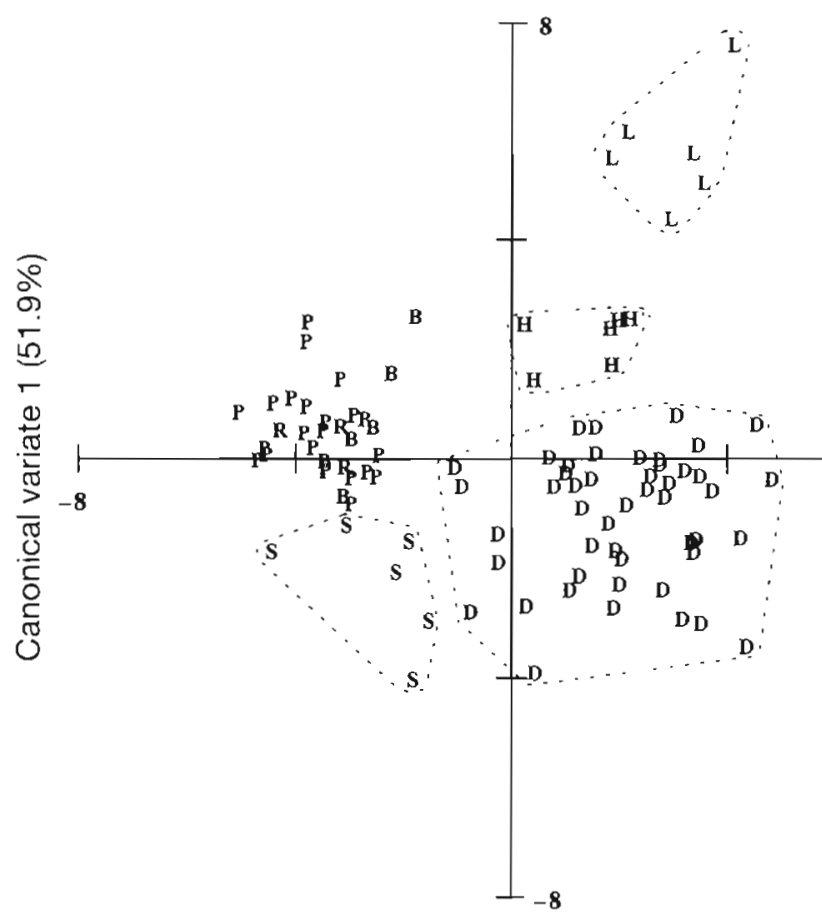

Canonical variate $2(23.7 \%)$ above suggest the groups $\mathrm{PB}$ and $\mathrm{PH}$ differ considerably from the other $P$. daedalea morphs in their skeletal characteristics and probably represent different morphological species. To examine the variation within $P$. daedalea, a CDA was performed only on those colonies which clustered together in the initial analyses (i.e. morphs PDC, PDF, PDFI, PDSV, PDSE; Fig. 2). The first 3 canonical variates explained $96 \%$ of the variation within the group. Plots of canonical variates (Fig. 4) showed clusters corresponding (although not completely) with the morphs PDC, PDSE, PDF and PDSV. Morph PDFI did not form a separate cluster in either of these plots nor was there evidence suggesting its morphological distinctness from plots of other canonical variables. Hence, the morph PDFI was combined with PDC (which it most closely resembles in the field) for the remainder of the analyses. The morph PDF was characterised by polyp area and theca thickness (Fig. 4A) and the group PDSV was strongly influenced by theca thickness, columella width and to a lesser extent septa per cm (Fig. 4A). Surprisingly, valley length was not a factor for discriminating PDSV, although mean values were considerably lower than for the other morphs (Table 1). The morph PDSE was separated by exertness of the septa and septa thickness (Fig. 4B). These results indicate that colonies representing the range of variation within a single species, $P$. daedalea, form part of a morphologic continuum and that the different morphs occur predictably at regions along this continuum.

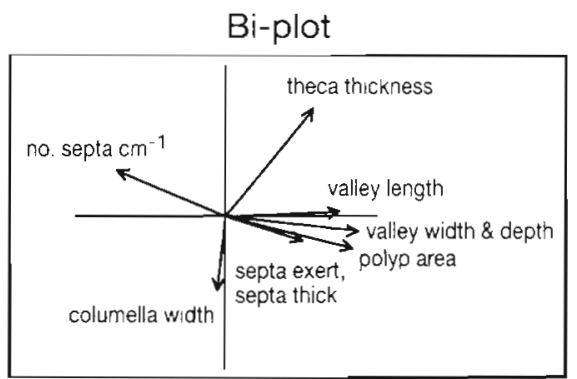

Fig. 2. Results from discriminant analysis of all Platygyra colonies; plot of first 2 canonical variates. D: P. daedalea; S: P. sinensis; P: P. pini; L: P. lamellina; R: P. ryukyuensis; $\mathrm{H}$ : species $\mathrm{PH}_{i} \mathrm{~B}$ : species $\mathrm{PB}$. Bi-plot shows relative contributions of each skeletal character 


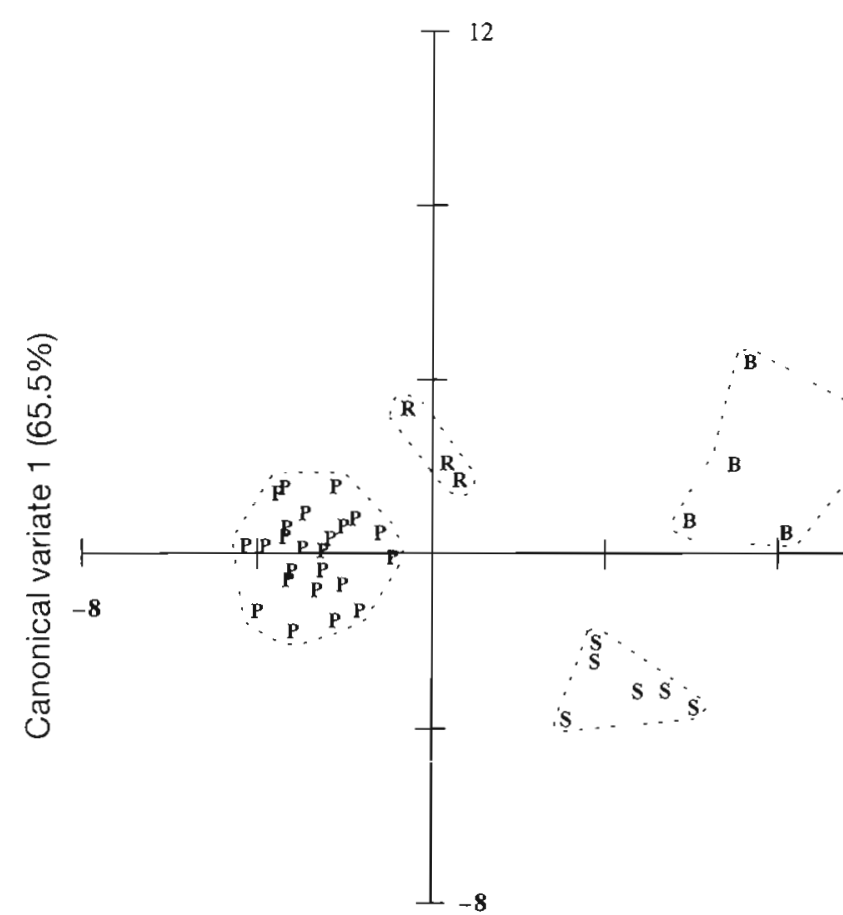

Canonical variate $3(15.6 \%)$

\section{Environmental variation}

The majority of Platygyra species occurred sympatrically within all 6 reef zones on Davies Reef (Fig. 5), although $P$. ryukyuensis and PB were restricted to reef flat habitats. The relative abundances of species and morphs differed across each zone (Fig. 5). ANOVAs indicated no significant difference in abundance of $P$. sinensis, $P$. daedalea (morph PDF), PB or PH across the 6 zones, however $P$. daedalea (morphs PDC, PDSE and PDSV) and $P$. pini were significantly more abundant in some zones (Table 2, Fig. 5)

Measured skeletal characteristics in Platygyra daedalea (morph PDC) and $P$. pinj were similar in colonies from the 4 different habitats (Table 3 ) and did not differ significantly between reef zones (MANOVA; $P$. daedalea: Pillai's Trace $=1.39, F=1.34, \mathrm{df}=27$, $\mathrm{p}<0.19 ;$ P. pini: Pillai's Trace $=0.96, F=0.73, \mathrm{df}=27$, $\mathrm{p}<0.79$ ). A nonsignificant result may reflect the inadequacy of the test to detect a difference, which in this case may be a result of insufficient replication. However, the initial pilot study indicated 10 replicate measurements of characters on 6 colonies was more than adequate to represent the population variance (see 'Methods') and variances on most characters are very low (Table 3). As such, nonsignificant results are likely to be real. These results indicate that habitat does not affect any of the 9 skeletal characteristics measured in these 2 species.

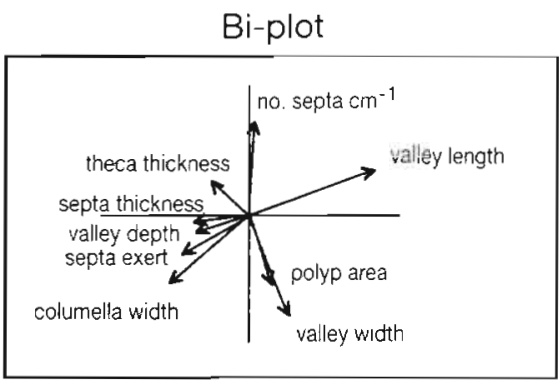

Fig. 3. Results from discriminant analysis of small-polyped Platygyra species; plot of first and third canonical variates. B: species PB; S: P. sinensis; P: P. pini, R: P. ryukyuensis. Biplot shows relative contributions of each skeletal character

\section{DISCUSSION}

Where skeletal characters appear to form a continuum between species, it is possible to use numerical methods to assist in the delineation of species groups.

Table 2. Results from ANOVAs comparing Platygyra species abundance (number of colonies) across 6 reef zones. Species that occurred in only 1 zone are not included. " $p<0.05$, $\cdots p<0.01, \cdots p<0.001$, ns: not significant

\begin{tabular}{|llrrrr|}
\hline Species/morph & $\begin{array}{l}\text { Source of } \\
\text { variation }\end{array}$ & $\mathrm{df}$ & $\mathrm{MS}$ & $F$ & $\mathrm{p}$ \\
\hline P. daedalea & & & & \\
PDC & Zone & 5 & 34.20 & 4.15 & $\ldots$ \\
& Site (zone) & 18 & 8.24 & 3.75 & $\ldots$ \\
PDF & Zone & 5 & 2.67 & 1.91 & $\mathrm{~ns}$ \\
& Site (zone) & 18 & 1.39 & 1.74 & $\cdot$ \\
PDSE & Zone & 5 & 73.27 & 19.03 & $\ldots$ \\
& Site (zone) & 18 & 3.85 & 1.05 & $\mathrm{n}$ \\
PDSV & Zone & 5 & 2.08 & 3.11 & $\cdot$ \\
& Site (zone) & 18 & 0.67 & 1.09 & $\mathrm{~ns}$ \\
P. pini & Zone & 5 & 76.93 & 12.33 & $\ldots$ \\
& Site (zone) & 18 & 6.24 & 1.60 & $\mathrm{~ns}$ \\
P. sinensis & Zone & 5 & 3.16 & 1.93 & $\mathrm{~ns}$ \\
& Site (zone) & 18 & 1.64 & 1.15 & $\mathrm{~ns}$ \\
$\mathrm{~PB}$ & Zone & 5 & 6.85 & 1.66 & $\mathrm{~ns}$ \\
& Site (zone) & 18 & 4.14 & 3.68 & $\ldots$ \\
$\mathrm{PH}$ & Zone & 5 & 0.26 & 1.48 & $\mathrm{~ns}$ \\
& Site (zone) & 18 & 0.17 & 0.78 & $\mathrm{~ns}$ \\
& & & & & \\
& & & & &
\end{tabular}




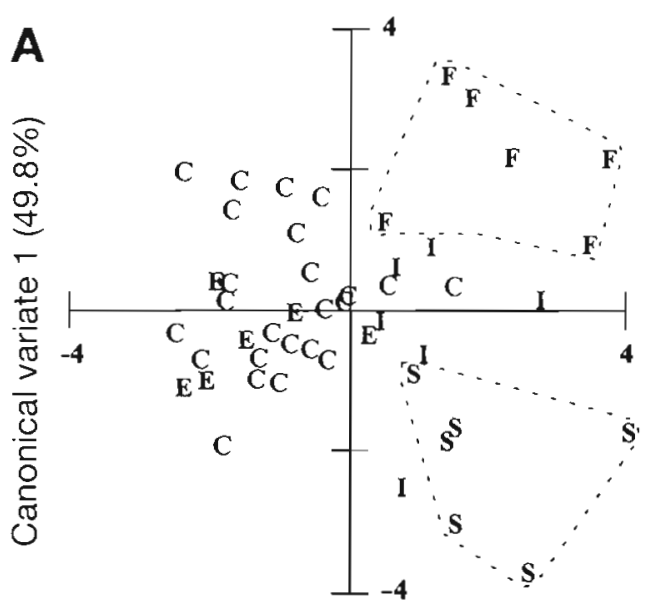

Canonical variate $2(30.0 \%)$
Fig. 4. Results from discriminant analysis of morphological variants of Platygyra daedalea. (A) Plot of canonical variates 1 and 2; (B) plot of canonical variates 2 and 3. C: morph PDC; E: morph PDSE; F: morph PDF; I: morph PDFI S: morph PDSV (see 'Methods' for description of morph codes). Bi-plots show relative contributions of each skeletal character
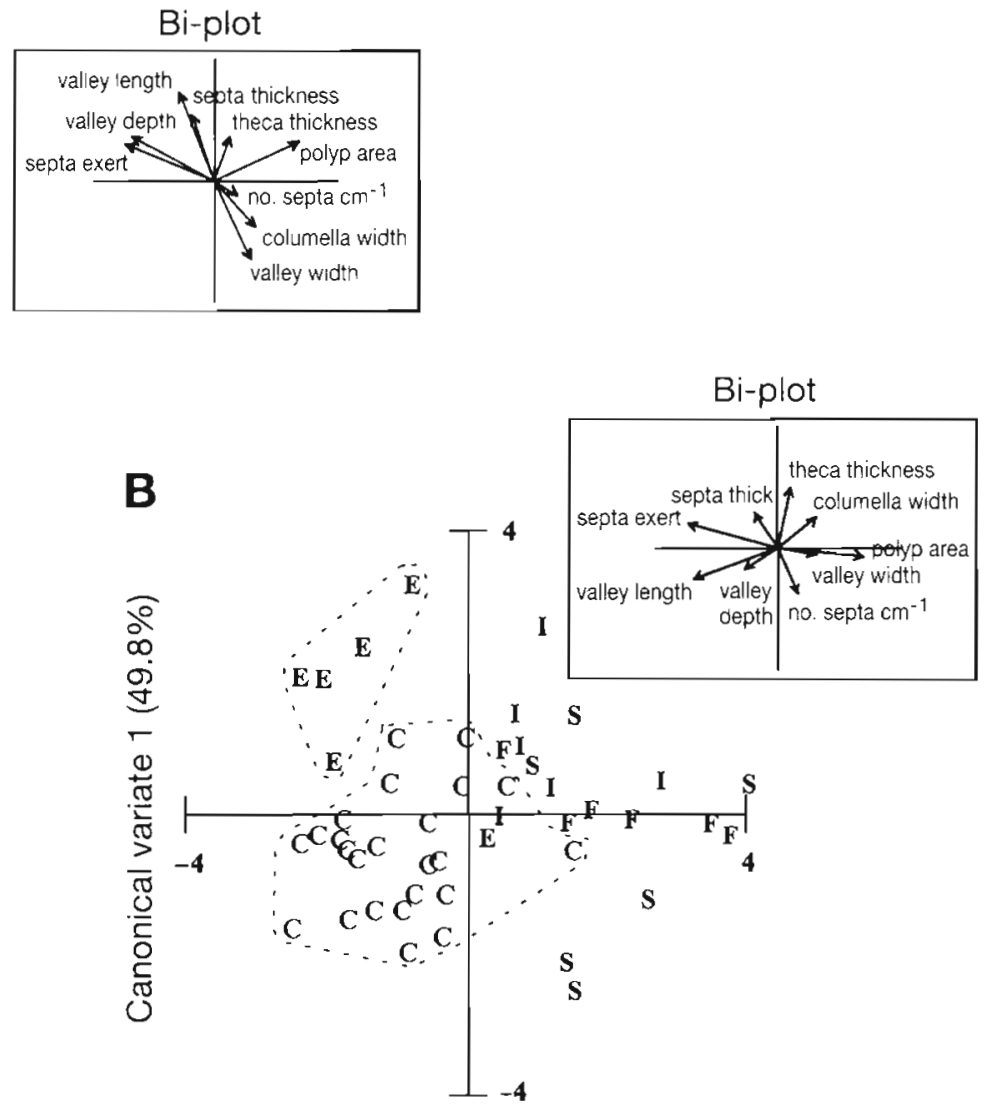

Canonical variate $3(16.3 \%)$

Table 3. Mean values (SD in parentheses) for 9 skeletal characters of Platygyra daedalea and P. pini from 4 different reef zones on Davies Reef ( $n=60$ for each zone; 6 colonies of each species with 10 replicate measurements of each character). All measurements are in $\mathrm{mm}$ (except polyp area which is $\mathrm{mm}^{2}$ ). Reef zones are F10: front reef slope at $10 \mathrm{~m}$ depth; F5: front reef slope at $5 \mathrm{~m}$ depth; LAG: lagoon; BACK: back reef slope at $5 \mathrm{~m}$ depth

\begin{tabular}{|c|c|c|c|c|c|c|c|c|}
\hline & \multicolumn{4}{|c|}{ P. daedalea } & \multicolumn{4}{|c|}{ P. pini } \\
\hline & F10 & F5 & $\mathrm{LAG}$ & BACK & $\mathrm{F} 10$ & F5 & $\mathrm{LAG}$ & $\mathrm{BACK}$ \\
\hline Valley length & $\begin{array}{c}125.5 \\
(110.9)\end{array}$ & $\begin{array}{l}116.6 \\
(72.4)\end{array}$ & $\begin{array}{c}74.5 \\
(47.3)\end{array}$ & $\begin{array}{c}83.2 \\
(55.4)\end{array}$ & $\begin{array}{c}6.7 \\
(1.4)\end{array}$ & $\begin{array}{c}6.6 \\
(1.3)\end{array}$ & $\begin{array}{c}7.0 \\
(1.1)\end{array}$ & $\begin{array}{c}7.0 \\
(1.2)\end{array}$ \\
\hline Valley width & $\begin{array}{c}6.9 \\
(0.8)\end{array}$ & $\begin{array}{c}6.7 \\
(0.8)\end{array}$ & $\begin{array}{c}7.2 \\
(0.9)\end{array}$ & $\begin{array}{c}7.7 \\
(1.0)\end{array}$ & $\begin{array}{c}5.1 \\
(0.7)\end{array}$ & $\begin{array}{c}4.9 \\
(0.7)\end{array}$ & $\begin{array}{c}5.3 \\
(0.7)\end{array}$ & $\begin{array}{c}5.3 \\
(0.9)\end{array}$ \\
\hline No. septa $\mathrm{cm}^{-1}$ & $\begin{array}{c}9.1 \\
(1.0)\end{array}$ & $\begin{array}{c}9.6 \\
(1.2)\end{array}$ & $\begin{array}{c}8.9 \\
(1.1)\end{array}$ & $\begin{array}{c}8.8 \\
(1.0)\end{array}$ & $\begin{array}{l}11.7 \\
(1.6)\end{array}$ & $\begin{array}{l}11.2 \\
(1.3)\end{array}$ & $\begin{array}{l}11.2 \\
(1.4)\end{array}$ & $\begin{array}{l}11.4 \\
(1.4)\end{array}$ \\
\hline Columella width & $\begin{array}{c}1.09 \\
(0.25)\end{array}$ & $\begin{array}{c}1.06 \\
(0.31)\end{array}$ & $\begin{array}{c}1.11 \\
(0.19)\end{array}$ & $\begin{array}{l}1.28 \\
(0.21)\end{array}$ & $\begin{array}{c}1.19 \\
(0.26)\end{array}$ & $\begin{array}{c}1.06 \\
(0.23)\end{array}$ & $\begin{array}{c}1.11 \\
(0.20)\end{array}$ & $\begin{array}{c}1.23 \\
(0.21)\end{array}$ \\
\hline Septa thickness & $\begin{array}{c}0.27 \\
(0.06)\end{array}$ & $\begin{array}{c}0.24 \\
(0.04)\end{array}$ & $\begin{array}{c}0.23 \\
(0.05)\end{array}$ & $\begin{array}{c}0.27 \\
(0.07)\end{array}$ & $\begin{array}{c}0.21 \\
(0.04)\end{array}$ & $\begin{array}{c}0.19 \\
(0.03)\end{array}$ & $\begin{array}{c}0.22 \\
(0.04)\end{array}$ & $\begin{array}{c}0.20 \\
(0.05)\end{array}$ \\
\hline Theca thickness & $\begin{array}{c}1.59 \\
(0.39)\end{array}$ & $\begin{array}{c}1.51 \\
(0.38)\end{array}$ & $\begin{array}{l}1.87 \\
(0.46)\end{array}$ & $\begin{array}{c}1.71 \\
(0.50)\end{array}$ & $\begin{array}{c}1.39 \\
(0.26)\end{array}$ & $\begin{array}{c}1.30 \\
(0.26)\end{array}$ & $\begin{array}{c}1.49 \\
(0.27)\end{array}$ & $\begin{array}{c}1.47 \\
(0.40)\end{array}$ \\
\hline Valley depth & $\begin{array}{c}5.1 \\
(0.8)\end{array}$ & $\begin{array}{c}5.1 \\
(0.8)\end{array}$ & $\begin{array}{l}4.6 \\
(0.9)\end{array}$ & $\begin{array}{c}5.6 \\
(0.8)\end{array}$ & $\begin{array}{c}2.3 \\
(0.7)\end{array}$ & $\begin{array}{c}2.7 \\
(0.7)\end{array}$ & $\begin{array}{c}2.7 \\
(0.8)\end{array}$ & $\begin{array}{c}2.8 \\
(0.7)\end{array}$ \\
\hline Exertness of septa & $\begin{array}{c}2.4 \\
(0.5)\end{array}$ & $\begin{array}{c}2.2 \\
(0.5)\end{array}$ & $\begin{array}{c}2.0 \\
(0.7)\end{array}$ & $\begin{array}{c}2.4 \\
(0.6)\end{array}$ & $\begin{array}{c}1.0 \\
(0.7)\end{array}$ & $\begin{array}{c}1.3 \\
(0.5)\end{array}$ & $\begin{array}{c}1.3 \\
(0.7)\end{array}$ & $\begin{array}{c}1.5 \\
(0.6)\end{array}$ \\
\hline Polyp area & $\begin{array}{l}48.4 \\
(6.8)\end{array}$ & $\begin{array}{l}45.9 \\
(4.6)\end{array}$ & $\begin{array}{c}49.2 \\
(10.1)\end{array}$ & $\begin{array}{c}54.3 \\
(11.7)\end{array}$ & $\begin{array}{l}24.0 \\
(6.5)\end{array}$ & $\begin{array}{l}22.7 \\
(5.3)\end{array}$ & $\begin{array}{l}26.8 \\
(6.5)\end{array}$ & $\begin{array}{l}27.9 \\
(8.1)\end{array}$ \\
\hline
\end{tabular}



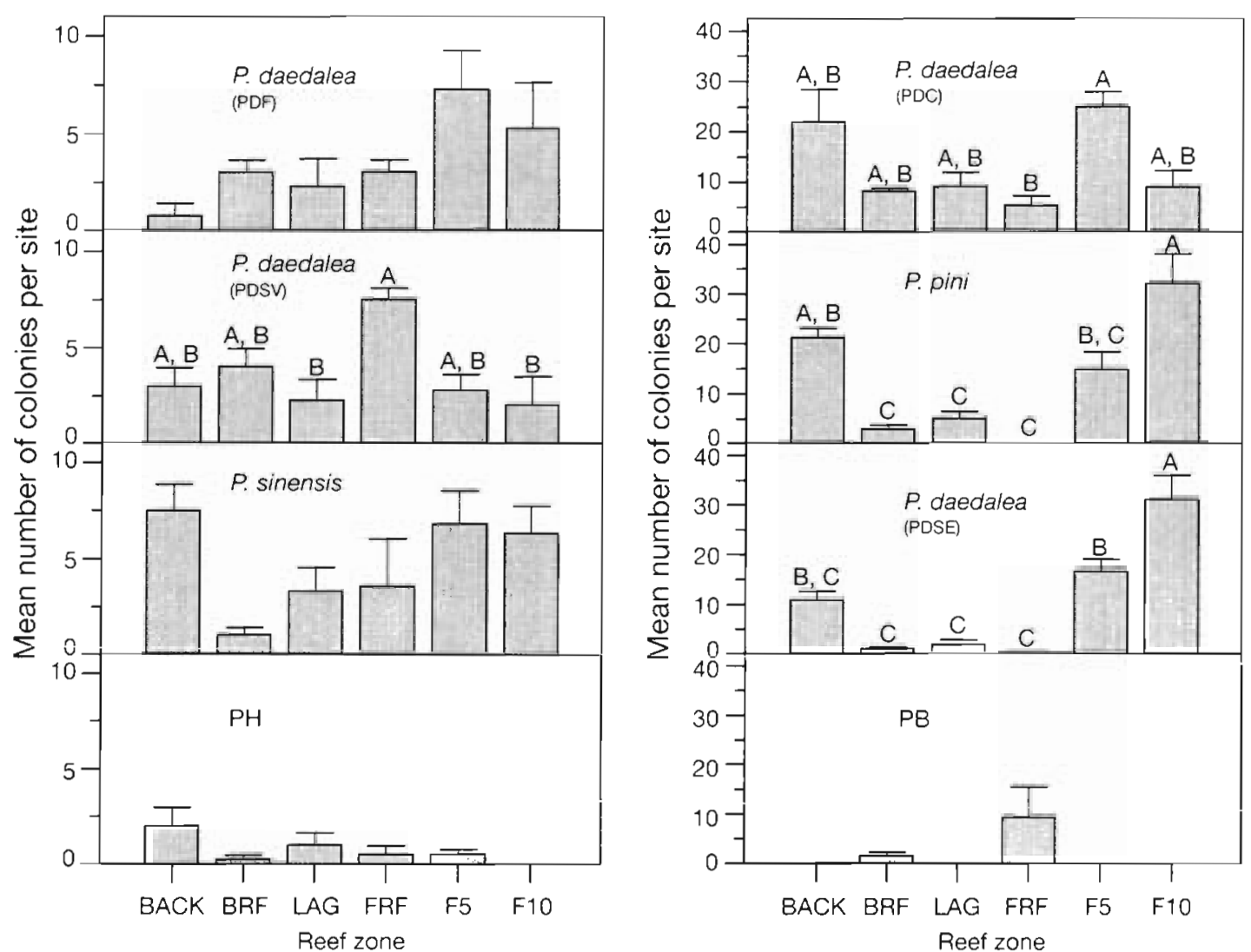

Fig. 5. Distribution of Platygyra species and morphs across 6 different reef zones: F1.0, front reef at $10 \mathrm{~m}$ depth; F5, front reef at $5 \mathrm{~m}$ depth; FRF, front reef flat; LAG, lagoon; BRF, back reef flat; BACK, back reef slope at $5 \mathrm{~m}$ depth. Sites consist of 8 replicate $20 \times 1 \mathrm{~m}$ belt transects, mean values are based on 4 sites in each reef zone. Bars indicate standard errors. Letters above error bars indicate Tukey's groupings for those species with significant ANOVAs on species abundance between reef zones (see Table 2). Zones with the same letter are not significantly different. N.B. P. ryukyuensis was not found in the transect survey, however colonies were seen on the FRF adjacent to the transect sites. Similarly PH was also seen adjacent to the transects at F10

No diagnostic skeletal characters existed between Platygyra species and skeletal characters were highly variable with overlapping ranges (Table 1). However, multivariate analysis successfully isolated 7 discrete morphological species groups (Figs. 2 \& 3). Five of these morphological groups correspond well with the species $P$. daedalea, $P$. lamellina, P. pini, $P$. ryukyuensis and $P$. sinensis which are currently recognised in the taxonomic literature. Two groups - $\mathrm{PB}$ and $\mathrm{PH}-$ do not appear to have any parallels in earlier literature and may represent new morphological species. The specific status of $P$. lamellina has been questioned in the past and it has often been synonymised with P. daedalea (Stephenson \& Wells 1955, Chevalier 1975). This study has shown that the 2 species are morphologically distinct and that their separate status should be maintained. Similarly, $P$, ryukyuensis is sometimes synonymised with $P$. sinensis (Chevalier 1975 , Veron et al. 1977) however the 2 species have been shown to be morphologically different in this study.
The range of variation within a species can also be understood using numerical methods. Platygyra daedalea could be divided into 4 discrete morphological groups (PDC, PDSV, PDSE, PDF) which differ in both colony form (see 'Methods') and in skeletal characters (Fig. 4). Variants within the species $P$. daedalea formed a discrete species group in the discriminant analysis when compared with other species (Fig. 2) and the 4 morphological variants occur predictably within the group (Fig. 4).

Intraspecific morphological variation in corals is often correlated with environmental influences (e.g. Foster 1980, Haggerty et al. 1980, Oliver et al. 1983, Willis 1985). Within Platygyra species, however, there appears to be no significant skeletal variation in either calicular characters or colony morphology that is related to habitat. Skeletal characters of colonies of both $P$. daedalea (morph PDC) and P. pini from 4 different reef zones were directly comparable (Table 3 ). Other species of Platygyra were also sympatric (Fig. 5) 
with no obvious changes in their colony morphology between reef zones, and morphological variants of P. daedalea do not correspond with habitat differences (Miller in press). The absence of any association between morphology and habitat in this study differs from the findings of Wijsman-Best (1974) who found decreases in the number of corallites per meander and the number of septa per $\mathrm{cm}$ with increasing depth in $P$. daedalea. Differences in sample sizes, sampling habitats or geographic variation may account for the discrepancies between the 2 studies. Similarly, Veron et al. (1977) suggested the morphology of $P$. daedalea colonies varied between habitats, however this variation was not quantified.

Environmental effects on morphology in some species have been assessed by transplant experiments (e.g. Foster 1979, Oliver et al. 1983, Willis 1985), but growth rates of Platygyra (Babcock 1991) are too slow to make this approach feasible. Microenvironmental influences on morphology may be important, particularly in highly heterogeneous environments such as coral reefs, however observations of living colonies in situ suggest microenvironment has little effect on overall colony morphology. Prevailing environmental conditions at the time of settlement could potentially affect the growth form of a colony, however this effect may be masked due to sampling a population comprising a number of different cohorts. Finally, it is unlikely that colony morphology is a factor of age as both small and large colonies of all species and morphs were seen on the reef (unpubl. data).

The majority of Platygyra species occurred sympatrically in different zones across the reef (Fig. 5) although $P$. pini was more abundant in deeper water than in shallow water (Fig. 5). P. daedalea (morph PDC) was significantly more abundant in F5 than on the FRF which may reflect the abundances of all corals in these 2 zones, since coral cover is much higher on the reef slope than on the reef flat at Davies Reef (pers. obs.). P. daedalea (morph PDSE) was more abundant in deeper water than in shallow while morph PDSV showed the opposite pattern. Some coral species may become plate-like with increasing depth (e.g. Barnes 1973, Dustan 1979, Willis 1985). The morph PDSE has a plate-like or encrusting morphology and while it is most abundant below $5 \mathrm{~m}$ (Fig. 5) it can be found in all reef zones, at depths ranging from 1 to $10 \mathrm{~m}$. Similarly, short-valleyed morphs were also widely distributed across zones (Fig. 5). The differing patterns of abundance of Platygyra species between zones may be accounted for by factors such as habitat selection by larvae or differential postsettlement mortality.

The absence of any association between morphology and habitat in Platygyra suggests that the environment is not the sole influence on morphology in these species.
Morphology may be genetically determined as has been demonstrated for other coral species (e.g. Pavona cactus; Willis 1985, Willis \& Ayre 1985). Certainly for P. daedalea, colony differences most likely occur from a combination of different factors including genotype (Miller in press). Organisms may display alternative adaptive strategies to environmental pressures and an inverse relationship between phenotypic plasticity and genotypic diversity has been hypothesised (Lewontin 1957. Marshall \& Jain 1968). Colonies of Platygyra display high genetic variation (Miller in press, K. J. Miller \& J. A. H. Benzie unpubl.) and it may be that these species utilise genetic variation rather than phenotypic plasticity to adapt to different environmental regimes.

This study has highlighted the applicability of numerical methods for defining species boundaries in highly variable, 'difficult' groups of corals. Similarly, these techniques are useful for understanding the ranges of intraspecific morphological variation. The main limitation of numerical analysis which must be taken into account is that it does not address the levels of difference between groups (e.g. subspecies, sibling species, ecomorphs), only that groups are morphologically different. It is important, therefore, to supplement morphometric analysis with other approaches in order to understand any apparent differences. Within Platygyra, morphological groups do not appear to be environmental variants of a single species and represent discrete morphological species. Similarly, variation within a single species is not related to habitat changes across the reef. However, the relationship between such 'morphological species' (as identified using multivariate techniques) and so called 'biological species' is unclear and it is unlikely to be straightforward (Miller in press). Genetic and reproductive data have shown the 7 morphological species of Platygyra are not genetically distinct nor are they reproductively isolated (Miller unpubl.), thus it cannot be assumed that morphological differences equate with biological species boundaries. Further work will be necessary to fully understand how morphological species boundaries relate to biological species boundaries in Platygyra and also to understand the implications of these results for coral evolution generally.

Acknowledgements. I thank Russ Babcock, Terry Hughes and Craig Mundy for assistance and support in this work. Natalie Moltschaniwskyj and 2 anonymous reviewers also provided useful suggestions on this manuscript. This research is in partial fulfilment of a Ph.D. and was supported financially by grants from the Australian Coral Reef Society and the Australian Museum (to K.J.M.) and by Australian Research Council Grants (to B. Willis/K. Miller/B. Stobart and to T. Hughes). Work was carried out with assistance from the Australian Institute of Marine Science and James Cook University of North Queensland. 


\section{LITERATURE CITED}

Babcock, R. C. (1991). Comparative demography of three species of scleractinian corals using age- and size-dependent classifications. Ecol. Monogr. 6: 225-244

Barnes, D. J. (1973). Growth in colonial scleractinians. Bull. mar. Sci. 23(2): 280-298

Brakel, W. H. (1977). Corallite variation in Porites and the species problem in corals. Proc. 3rd int. Coral Reef Symp. 1: $457-462$

Chevalier, J. P. (1975). Les scléractinaires de la Mélanésie Française (Nouvelle Calédonie, lles Chesterfield, Iles Layauté, Nouvelles Hébrides), 2ème Partie. Expéd. française récifs coralliens Nouvelle Calédonie. Vol. 7. Edn. Fond. Singer-Polignac, Paris

Dustan, P. (1975). Growth and form in the reef-building coral Montastrea annularis. Mar. Biol. 33: 101-107

Dustan, P. (1979). Distribution of zooxanthellae and photosynthetic chloroplast pigments of the reef-building coral Montastrea annularis Ellis and Solander in relation to depth on a West Indian coral reef. Bull, mar. Sci. 29(1): $79-95$

Ellis, J., Solander, D. (1786). The natural history of many curious and uncommon zoophytes. Benjamin White and Peter Elmsly, London

Foster, A. B. (1979). Phenotypic plasticity in the reef corals Montastrea annularis (Ellis and Solander) and Siderastrea siderea (Ellis and Solander). J. exp. mar. Bioi. Eccol. 39. $25-54$

Foster, A. B. (1980). Environmental variation in skeletal morphology within the Caribbean reef corals Montastrea annularis and Siderastrea siderea. Bull. mar. Sci. 30(3): $678-709$

Graus, R. R., Macintyre, I. G. (1982). Variation in growth forms of the reef coral Montastrea annularis (Ellis and Solander): a quantitative evaluation of growth response to light distribution using computer simulation. The Atlantic Barrier Reef ecosystem at Carrie Bow Cay, Belize, 1. Structure and communities. Smithson. Contrib. mar. Sci. 12: 441-464

Haggerty, J. A., Weber, J. N., Cuffey, R. J., Deines, P. (1980). Environment-related morphologic and geochemical variability in the modern reef corals Favia pallida and Favia stelligera on Enewetak atoll. Pacif. Geol. 14: 95-112

Huxley, J. (1938). Clines: an auxiliary taxonomic principle. Nature 142: 219-220

Jaubert, J. (1977). Light, metabolism and growth forms of the hermatypic scleractinian coral Synaraea convexa Verrill in the lagoon of Moorea (French Polynesia). Proc. 3rd int. Coral Reef Symp. 1: $483-4.88$

Lang, J. C. (1984). Whatever works: the variable importance of skeletal and non-skeletal characters in scleractinian taxonomy. Palaeontogr. Am. 54: 18-44

Lewontin, R. C. (1957). The adaptation of populations to varying environments. Cold Springs Harbour Symp. Quant. Biol. 22: 395-408

This article was presented by R. H. Karlson (Senior Editorial Advisor), Newark, Delaware, USA
Marshall, D. R., Jain, S. K. (1968). Phenotypic plasticity of Avena fatua and A barbata. Am. Nat. 102(927): 457-467

Miller, K. J. (1994). The Platygyra species complex: implications for coral taxonomy and evolution. Ph.D. dissertation, James Cook University of North Queensland, Townsville

Miller, K. J. (in press). Morphological variation in the scleractinian coral Platygyra daedalea (Ellis and Solander, 1786) - genetically or environmentally determined? Proc. 7th int. Coral Reef Symp

Oliver, J. K., Chalker, B. E., Dunlap, W. C. (1983). Bathymetric adaptations of reef-building corals at Davies Reef, Great Barrier Reef, Australia. 1. Long-term growth responses of Acropora formosa (Dana 1846). J. exp. mar. Biol. Ecol 73: 11-35

Powers, D. A., Rohlf, F. J. (1972). A numerical taxonomic study of Caribbean and Hawaiian reef corals. Syst. Zool. 21: $53-64$

Stephenson, W., Wells, J. W. (1955). The corals of Low Isles, Queensland. August, 1954. Univ. Queensl. Pap. Dept Zool. 1, 4: 1-59

Turesson, G. (1922). The genotypical response of the plant species to the habitat. Hereditas 3: 211-350

Van Veyhel, M. L. J., Bak, R. P. M. (1993). Intraspecific variation of a dominant Caribbean reef building coral, Montastrea annularis: genetic behavioural and morphometric aspects. Mar. Ecol. Prog. Ser. 92: 255-265

Vaughan, T W., Wells, J. W. (1943). Revision of the suborders, families and gonera of the Scleractinia. Geol. Sor Am. Spec. Pap. 44: 1-363

Veron, J. E. N. (1981). The species concept in 'Scleractinia of Eastern Australia' Proc. 4th int. Coral Reef Symp. 2: $183-186$

Veron, J. E. N. (1986). Corals of Australia and the Indo-Pacific. Angus and Robertson Publishers, Sydney

Veron, J. E. N. (1993). A biogeographic database of hermatypic corals. Species of the central Indo-Pacific, genera of the world. Monogr. Ser. Aust. Inst. mar. Sci. 10: 1-433

Veron, J. E. N., Pichon, M. (1976). Scleractinia of eastern Australia, Part 1, Families Thamnasteriidae, Astrocoeniidae, Pocilloporidae. Monogr. Ser. Aust. Inst. mar. Sci. 1: 1-86

Veron, J. E. N., Pichon, M., Wijsman-Best, M. (1977). Scleractinia of eastern Australia, Part 2, Families Faviidae, Trachyphyllidae. Monogr. Ser. Aust. Inst. mar. Sci. 3: 1-233

Wallace, C. (1974). A numerical study of a small group of Acropora specimens (Scleractinia: Acroporidae). Mem. Queensl. Mus. 17: 55-61

Wijsman-Best, M. (1974). Habitat-induced modification of reef corals (Faviidae) and its consequences for taxonomy. Proc. 2nd Coral Reef Symp. 2: 217-228

Willis, B. L. (1985). Phenotypic plasticity versus phenotypic stability in the reef corals Turbinaria mesenterina and Pavona cactus. Proc. 5th int. Coral Reef Symp. 4: 107-112

Willis, B. L., Ayre, D. J. (1985). Asexual reproduction and genetic determination of growth form in the coral Pavona cactus: biochemical genetic and immunogenic evidence. Oecologia 65: 516-525

Manuscript first received: October 14, 1993

Revised version accepted: February 24, 1994 